\title{
BIMBINGAN DAN PENGARAHAN TENTANG KIAT SUKSES MEMULAI USAHA DI BIDANG MAKANAN PKK RT 13 RW 08 KELURAHAN BARENG KECAMATAN KLOJEN KOTA MALANG
}

\author{
Shinta Maharani Trivena, Rena Feri Wijayanti, Lina Budiarti, Tri Yulistyawati Evelina, Nilawati Fiernaningsih \\ shintamaharanitrivena@gmail.com \\ (triveevelina@gmail.com)
}

\begin{abstract}
Abstrak - This Community Service activity was held on Sunday 3 May 2019 in PKK RT 13 RW 8 Bareng, Klojen District Malang City. This activity is divided into several stages, namely the preparation stage, including the preparation of places and events, the stage of material delivery, the discussion stage, and the closing stage. The goals achieved are to To open trainees' insights that opportunities around are potential to be utilized so that they can produce economic value.

The success in community service can be seen from the enthusiasm of the trainees who are actively discussing and asking questions. The activity was attended by almost all PKK management and members. Participants want on going activities.
\end{abstract}

Kata kunci: food business.

\section{PENDAhULUAN}

\subsection{Latar Belakang}

Bisnis makanan di Kota Malang ini sangat memiliki peluang besar bagi masyarakat. Di tengah padatnya penduduk dan permintaan akan kebutuhan pokok yang tinggi, membuat banyak pedagang di Kota ini yang laris manis menjalankan usahanya. Namun demikian tidak semua pedagang makanan dapat going concern dalam melakukan usahanya. kegigihan dan semangat kewirausahaan menjadi kunci penting yang harus dimiliki oleh para pelaku bisnis.

Memasak menjadi tuntutan tersendiri bagi seorang wanita. Wanita haruslah bisa memasak, minimal untuk menyediakan makanan yang sehat bagi keluarga. Selain itu, bagi sebagian wanita hobby memasak ini dapat dijadikan lahan untuk menghasilkan pundi-pundi rupiah. Tetapi tidak semua wanita paham benar bagaimana menjadikan hobby memasak ini menjadi peluang bisnis. Tidak sedikit anggota PKK RT 13 RW 08 Kelurahan Bareng yang memiliki bakat dalam hal memasak, tetapi hanya segelintir orang yang memanfaatkan bakat tersebut untuk dikembangkan menjadi sebuah usaha yang potensial.

Bimbingan dan Pengarahan bagi anggota PKK RT 13 RW 08 Kelurahan Bareng Kecamatan Klojen Kota Malang diperlukan oleh bagi anggota PKK untuk dapat mengembangkan hobby memasak menjadi sebuah ladang bisnis yang dapat membantu perekonomian keluarga.

\section{KAJIAN LITERATUR}

\subsection{Kewirausahaan}

Kewirausahaan pada hakikatnya merupakan sikap, jiwa, untuk menciptakan sesuatu yang baru yang sangat bernilai dan berguna bagi dirinya dan bagi orang lain. Kwirausahaan merupaka sikap mental dan jiwa yang selalu aktif dan kreatif berdaya, bercipta, berkarsa, dan bersahaja dalam rangka meningkatkan pendapatan dalam kegiatan usahanya atau kiprahnya (Shalahuddin, 2012)

\subsection{Wirausaha}

Wirausaha atau wiraswasta menurut seseorang yang menciptakan usaha atau bisnis yang dihadapkan dengan risiko dan ketidakpastian untuk memperoleh keuntungan dan mengembangkan bisnis dengan cara mengenali kesempatan dan memanfaatkan sumber daya yang diperlukan (Suharyadi, dkk 2007:7)

\subsection{Kemampuan Yang Harus Dimiliki Oleh Wirausaha}

Menurut Suryana (2010:55) mengemukakan beberapa kemampuan yang harus dimiliki oleh wirausaha yaitu: self knowledge (pengetahuan tentang usaha), imagination (imajinasi), praticial knowledge (pengetahuan praktis), search skill (berkreasi), forseight (berpandangan jauh kedepan), computation skill (kemampuan untuk berhitung), communication skill (kemampuan untuk berkomunikasi)

\subsection{Hambatan dalam Mengembangkan Usaha}

Adapun sebab-sebab atau hambatan dalam mengembangkan usaha menurut Dianawati (2007) adalah karena:

- Trauma

- Tidak tahu cara memulai dan

\subsection{Alternatif Pendanaan Modal Usaha}

Alternatif pendanaan menurut Dianawati (2007) adalah:

- Dana yang dimiliki sendiri

- Tagihan kepada pihak lain atau piutang orang lain

- Hasil penjualan barang berharga

- Meminjam dana keluarga

- Hasil tarikan kartu kredit

- Peminjaman dana dari bank

- Meminjam kepada lembaga keuangan.

\subsection{Usaha di Bidang Makanan}

Usaha dibidang makanan adalah usaha yang tidak pernah ada matinya karena setiap saat orang 
membutuhkan makanan. Apabila makanan yang diperjual belikan memiliki citarasa yang nikmat maka orang akan kembali untuk membeli makanan yang dijual. Usaha dibidang makanan juga dapat dijalanankan di rumah dan tidak selalu harus membuka rumah makan, warung, atau depot.

\subsection{Kunci Sukses Memulai Usaha Makanan}

Kunci sukses Memulai usaha makanan menurut Alamsyah (2008):

- Punya visi

- Terencana

- Konsep pemasaran

\subsection{Tips Berbisnis Makanan}

Ada beberapa tips berbisnis makanan menurut Dianawati, (2007)

- Pengenalan dan penjajakan

- Harus enak

- Tampilan menarik

- Pelayanan

- Mengatur keuangan

\subsection{Tahap Persiapan Operasional}

Tahap persiapan operasional memulai usaha menurut Alamsyah (2008):

- Menentukan lokasi yang tepat

- Cara menyusun menu masakan yang tepat

- Menentukan harga jual yang tepat

- Menyusun resep rahasia yang tepat

\section{TUJUAN DAN MANFAAT}

\subsection{Tujuan Kegiatan}

- Memberikan sharing ilmu tentang kiat sukses memulai usaha di bidang makanan

- Membuka wawasan peserta pelatihan bahwa peluang di sekitar sangat potensial

- Meningkatkan ketrampilan peserta pelatihan dalam hal memasak

- Menambah pendapatan masyarakat

- Sebagai solusi bagi yang tetap ingin bekerja tetapi tidak ingin meninggalkan anak

- Bentuk pengabdian kalangan akademisi kepada masyarakat.

\subsection{Manfaat Kegiatan}

- Peserta pelatihan

- Peserta pelatihan mendapatkan banyak wawasan dan ilmu baru mengenai kiat sukses memulai usaha di bidang makanan.

- Penulis

- Mengaplikasikan ilmu manajemen baik keuangan, pemasaran, maupun operasional kepada masyarakat.

\subsection{Tahap Persiapan}

Ketua pelaksana berkoordinasi dengan salah satu pengurus PKK, mengenai tempat, konsep acara, serta waktu pelaksanaan. Pengurus PKK menyampaikan informasi ini kepada Ketua PKK dan disambut baik oleh ketua PKK. Ketua PKK meneruskan kepada anggota PKK mengenai rencana diadakan kegiatan pelatihan ini. Seluruh anggota PKK menyambut baik dan antusias mengenai penyelenggaraan kegiatan ini. Banyak anggota PKK yang sudah memulai berbisnis dibidang makanan tapi masih terkendala banyak hal seperti penakaran resep yang kurang pas, tidak tahu cara pemasarannya, tidak memiliki modal sehingga usahanya terhenti dan sebagainya. Oleh karena itu, dengan adanya kegiatan ini diharapkan membantu para peserta pelatihan untuk mengatasi permasalahan yang sedang dihadapi.

Berikut ini adalah dokumentasi sebelum dimulainya kegiatan

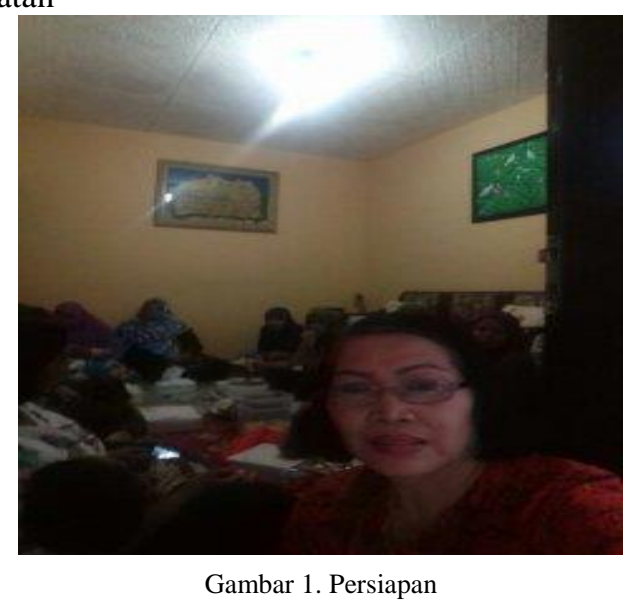

Pada kegiatan praktek ini yang dipraktekkan adalah cara penyajian, sehingga dibutuhkan lauk pauk dan nasi serta garnis yang akan dikemas menjadi sebuah nasi kotak yang penyajiannya menarik. Berikut ini adalah dokumentasinya:

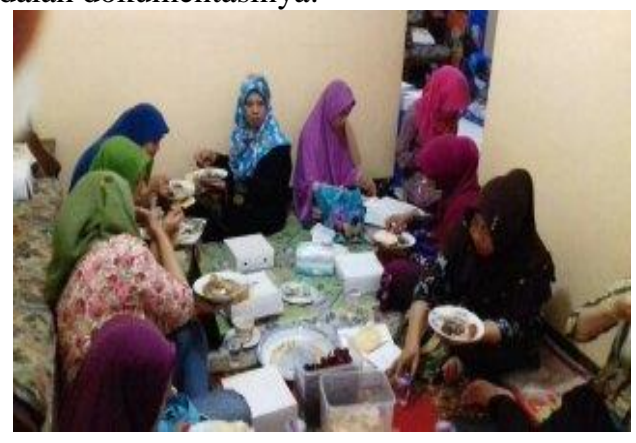

Gambar 2. Praktek

\subsection{Tahap Penyampaian Materi}

Penyelenggaraan kegiatan dimulai dengan pembukaan dari Ketua PKK, serta penyampaian informasi kegiatan mengenai PKK selama satu bulan terakhir. Setelah itu dilanjutkan dengan arisan PKK. Selanjutnya Ketua PKK mempersilahkan pemateri untuk menyampaikan maksud kegiatannya dan dilanjutkan dengan pemaparan materi. Berikut ini adalah dokumentasi saat arisan PKK berlangsung 


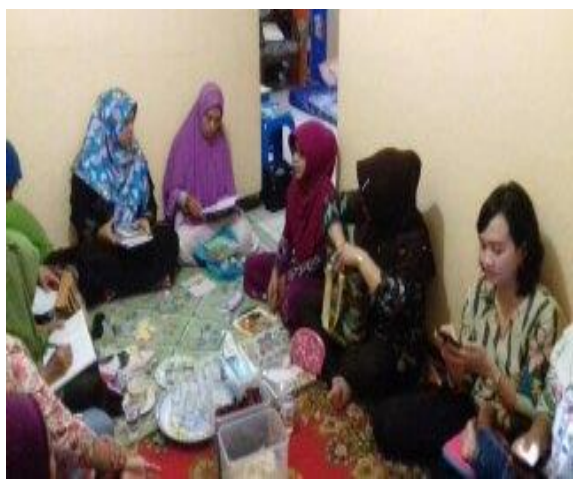

Gambar 4. Praktek

Adapun runtutan materi yang disampaikan dalam kegiatan ini adalah:

\section{Penyampaian latar belakang}

Berbagai peluang bisnis terbuka lebar di Kota Malang, baik bisnis perdagangan barang maupun jasa. Salah satu bisnis yang tidak ada matinya adalah bisnis di bidang makanan. Bisnis makanan menjadi peluang emas bagi masyarakat, terbukti dari banyaknya pedagang makanan yang sukses. Berikut ini adalah dokumentasinya:

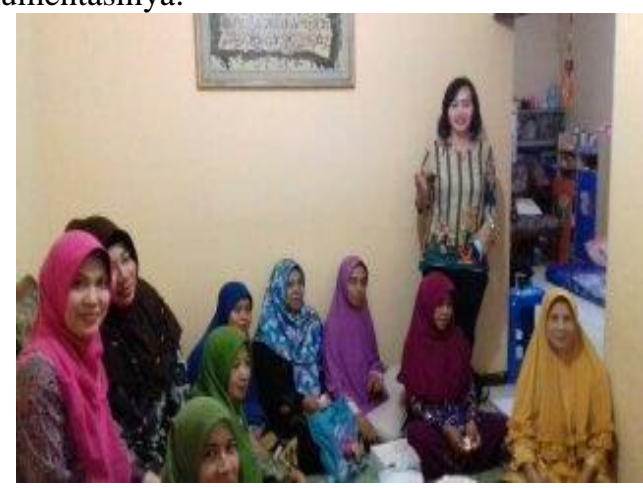

Gambar 5. Evaluasi

\section{Diskusi dan Tanya Jawab}

Dilakukan tanya jawab mengenai adakah diantara peserta yang telah memiliki usaha dibidang makanan. Hasilnya ada beberapa peserta yang menjawab bahwa mereka sedang menggeluti kegiatan usaha dibidang makanan. Pemateri kemudian menanyakan mengenai kendala yang dihadapi. Ternyata banyak perserta yang mengeluhkan mengenai permodalan, resep, dan pemasaran. Kendala yang paling utama adalah resep masakan dan pemasaran. Berikut ini adalah dokumentasi proses diskusi:

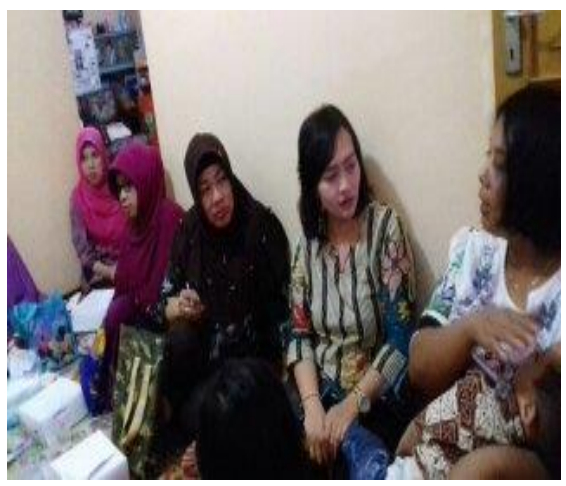

1) Permodalan
Cara mendapatkan modal:

(1) Tabungan

(2) Menjual asset

(3) Peminjaman kepada Bank

2) Pencarian Suplier

Menentukan supplier supplier bahan makanan antara lain:

(1) Kualitas Bahan Baku Makanan

(2) Harga Bahan Baku

(3) Jumlah Pasokan

(4) Pengembalian Produk

(5) Layanan Cepat Tanggap

\section{3) Analisis pesaing}

Harus dipahami cara-cara yang dapat dilakukan untuk menghadapi pesaing:

(1) Konsep yang matang

(2) Perencanaan matang menghadapi persaingan bisnis

(3) Evaluasi dan inovasi menetapkan Standar Produk

(4) Ramah dan jujur

4) Penakaran Resep Masakan

Penakaran resep masakan dimaksudkan untuk mengetahui jumlah bahan baku yang akan digunakan untuk memasak agar sesuai dengan takaran dan tidak mengubah rasa masakan

5) Penentuan Harga Jual Makanan

(1) Menentukan Konsumen

(2) Menganalisis Pesaing

(3) Melakukan Perhitungan atas Biaya

(4) Penyajian makanan

(5) Pengemasan

(6) Pengelolaan keuangan

(7) Pemasaran

6) Pengelolaan Keuangan

(1) Pisahkan keuangan pribadi dengan milik perusahaan

(2) Gunakan pembukuan keuangan

(3) Rencanakan dengan baik penggunaan uang

(4) Memastikan perhitungan keuntungan dengan benar

(5) Mengontrol aset, hutang serta kondisi modal

(6) Merencanakan pengembangan usaha dari hasil keuntungan

\section{7) Pemasaran}

(1) Buatlah tester dalam porsi kecil

(2) Memanfaatkan Momentum

(3) Membuat Selebaran

(4) Memanfaatkan Media Sosial

(5) Perkenalkan Bisnis Anda ke Instansi Terdekat

(6) Bekerjasama Dengan Agen Perjalanan

(7) Menjadi Mitra Perusahaan Ojol

(8) Membuat Promo Harga Khusus

\subsection{Khalayak Sasaran}

Anggota PKK RW 13 RT 08 Kelurahan Bareng Kecamatan Klojen Kota Malang.

\subsection{Metode Alih Pengetahuan}


Pemateri memberikan gambaran terlebih dahulu mengenai peluang bisnis makanan di Kota Malang, dimana bisnis di bidang makanan adalah bisnis yang tidak ada matinya dan memiliki margin keuntungan yang cukup besar. Setelah itu pemateri memberkan tips atau kiat-kiat sukses dalam menjalani bisnis di bidang makanan supaya jangan sampai gulung tikar di tengah jalan. Tips yang diberikan tersebut merupakan aplikasi dari ilmu manajemen baik manajemen operasional, manajemen pemasaran, dan Manajemen Sumber Daya Manusia.

\section{Metode Diskusi dan Tanya Jawab}

Sesi diskusi ini adalah sesi dimana para peserta dan pemateri saling tukar ilmu. Bukan hanya pemateri yang menjawab pertanyaan dari peserta, tetapi sesame peserta juga saling tukar pendapat. Bukan hanya peserta yang mendapatkan transfer pengetahuan dari pemateri, akan tetapi, pemateri juga mendapatkan pengetahuan dari pengalaman para peserta kegiatan.

\section{PEMBAHASAN MASALAH}

Ada beberapa orang yang telah berkecimpung dalam dunia bisnis makanan ini, tetapi tidak banyak yang pada akhirnya bisa survive dalam menjalani bisnis makanan ini. Permasalahan yang terjadi adalah tidak sedikit dari pelaku bisnis tersebut yang memiliki jiwa kewirausahaan dimana seorang wirausaha harus pantang menyerah. Kegagalan yang seharusnya dijadikan pelajaran telah membuat pelaku bisnis menyerah. Kegagalan tersebut meliputi, ketidak konsistenan rasa makanan yang dijual yang disebabkan karena tidak pas dalam menakar resep sehingga makanan yang dibuat memiliki rasa yang berbeda terutama jika memasak dalam jumlah besar. Kedua, ketidakmampuan dalam memasarkan barang dagangan. Hal ini disebabkan karena minimnya promosi yang dilakukan dan masih terbatasnya jaringan, serta minimnya pengetahuan para peserta mengenai pemasaran melalui online.

\subsection{Evaluasi Sebelum Kegiatan PKM}

Sebelum kegiatan Pengabdian kepada Masyarakat dimulai adalah mengajukan ijin kegiatan kepada ketua PKK mengenai penyelenggaraan kegiatan. Kegiatan diselenggarakan bertepatan dengan pertemuan rutin PKK pada setiap bulannya. Pada awalnya, penyelenggara kegiatan berencana mengundang owner Inggid Seafood untuk memberikan gambaran mengenai kesuksesan bisnis yang dijalaninya dan memberikan tips kepada peserta yang ingin memulai usaha dibidang makanan. Akan tetapi, dikarenakan banyaknya pesanan, maka owner tidak dapat memenuhi undangan.

\subsection{Evaluasi Selama Kegiatan PKM}

- Melakukan evaluasi mengenai waktu kehadiran

- Sulit mencari tempat parkir dikarenakan akses lokasi yang cukup susah dijangkau, terutama dengan roda empat. Sepanjang jalan menuju lokasi tidak cukup lebar sehingga tidak dapat parkir di jalan ataupun dilokasi. Oleh karena itu, harus mencari tempat parkir yang cukup jauh dari lokasi dan harus naik becak dan dilanjutkan dengan jalan kaki untuk dapat tiba di lokasi.

- Melakukan evaluasi mengenai penyampaian materi

- Tidak semua peserta telah terjun menekuni dunia bisnis makanan, sehingga yang aktif bertanya dan berdiskusi kebanyakan adalah peserta yang telah terjun menekuni usaha bisnis di bidang makanan. Meskipun begitu, semua peserta tetap memiliki antuasias yang tinggi untuk mengikuti kegiatan ini.

\subsection{Evaluasi Akhir Kegiatan PKM}

- Evaluasi mengenai kendala yang dihadapi peserta selama kegiatan berlangsung yakni keterbatasan tempat dan susahnya akses lokasi.

- Evaluasi mengenai keaktifan diskusi peserta.

- Pada dasarnya peserta kegiatan telah sangat antusias dalam mengikuti kegiatan ini hal ini terbukti dari sesi diskusi dan tanya jawab yang aktif. Hanya saja yang lebih aktif adalah peserta yang telah memiliki pengalaman membuka usaha dibidang bisnis makanan

- Evaluasi Pada Akhir Kegiatan

- Kegiatan ini berakhir pukul 17.00 dan ditutup oleh ketua PKK dan tuan rumah. Secara garis besar acara telah berlangsung dengan baik. Pengabdian kepada Masyarakat ini telah diikuti oleh peserta dengan penuh antuiasme.

\subsection{Hasil}

- Menerapkan pengetahuan dibidang manajemen, baik manajemen operasional, manajemen keuangan, manajemen pemasaran, dan manajemen sumber daya manusia

- Menciptakan peluang kerja, khususnya bagi ibu rumah tangga yang ingin menambah penghasilan

- Mengembangkan kreatifitas khususnya dalam hal memasak, untuk dapat dikomersialisasikan

- Menambah wawasan tentang dunia bisnis di bidang makanan

\section{Faktor Penghambat}

- Terbatasnya waktu yang diberikan

- Tempat yang kurang luas

- Tidak hadirnya owner "Inggit Seafood", yang telah diundang untuk memberikan tambahan materi

- Tidak adanya lahan parkir sehingga menyebabkan keterlambatan acara

\section{Faktor Pendorong}

- Keterbukaan dan keramahan para peserta

- Semangat para peserta yang dilihat dari keaktifan selama diskusi

- Sikap kooperatif para peserta

- Bantuan tuan rumah untuk menyiapkan perlengkapan dan peralatan 


\subsection{Luaran yang Dicapai}

Luaran yang dicapai adalah adanya alih pengetahuan khususnya dalam hal manajemen, baik manajemen operasional, manajemen keuangan, manajemen pemasaran, dan manajemen sumber daya manusia. Alih pengetahuan ini dapat digunakan sebagai modal bagi para peserta untuk bekal menjalankan usahanya. Selain itu, luaran yang dicapai adalah publikasi ilmiah berupa jurnal nasional yakni jurnal abdimas.

\section{V.KESIMPULAN}

Kegiatan Pengabdian Masyarakat ini dilaksanakan pada, Minggu 3 Mei 2019 di PKK RT 13 RW 8 Kelurahan Bareng Kecamatan Klojen Kota Malang. Tujuan yang dicapai adalah untuk membuka wawasan peserta pelatihan bahwa peluang di sekitar sangat potensial untuk dimanfaatkan sehingga menjadi suatu yang dapat menghasilkan nilai ekonomis.

Kegiatan ini juga memberikan bekal ilmu dari hasil alih pengetahuan dalam hal pengelolaan usaha di bidang makanan bagi pelaku usaha baru untuk dapat memahami dan mengaplikasikan ilmu manajemen operasional, manajemen keuangan, manajemen pemasaran, dan manajemen sumber daya manusia sehingga tercipta peluang kerja.

Serangkaian kegiatan mulai dari tahap awal sampai dengan akhir diikuti peserta dengan penuh antusiasme, terbukti dari sikap keramahan dan keterbukaan para peserta dalam menyambut tim pemateri. Selain itu, selama proses diskusi dan pelatihan diikuti dengan penuh antusias.

\section{Saran}

- Diharapkan ada tindakan keberlanjutan, sehingga ilmu yang telah disampaikan tidak berakhir dengan sia-sia

- Perlu adanya kegiatan kegiatan pendampingan bagi calon pelaku usaha baru di bidang bisnis makanan

- Diperlukan kerjasama dengan ETU Polinema untuk melakukan pendampingan kepada calon pengusaha baru

\section{DAFTAR PUSTAKA}

[1]. Alamsyah, Yuyun. 2008. Bangkitnya Kuliner Tradisional. Jakarta: PT. Elex Media Komputindo

[2]. Dianawati, Ajen. 2007. Peluang Usaha Rumahan Yang Menguntungkan. Jakarta: Mediakita

[3]. Harmaizar. 2009. Menangap Peluang Usaha. Bekasi: CV Dian Anugrah Prakasa

[4]. Suryana, Yuyus dan Bayu, Kartib 2010, Kewirausahaan Pendekatan Karakteristik Wirausahawan Sukses. Prenamedia Group, Bandung

[5]. Shalahuddin dkk. 2012. Prinsip-Prinsip Dasar Kewirausahaan. Yogyakarta : CV Budi Utama

[6]. Suharyadi, dkk. 2007. Kewirausahaan. Jakarta: Salemba Empat 